O. A. Vasilyeva

\title{
Agro-food clusters in the Republic of Kazakhstan: assessment and prospects of development
}

\section{KEYWORDS}

cluster;

agricultural cluster;

cluster policy;

agricultural enterprises;

farms

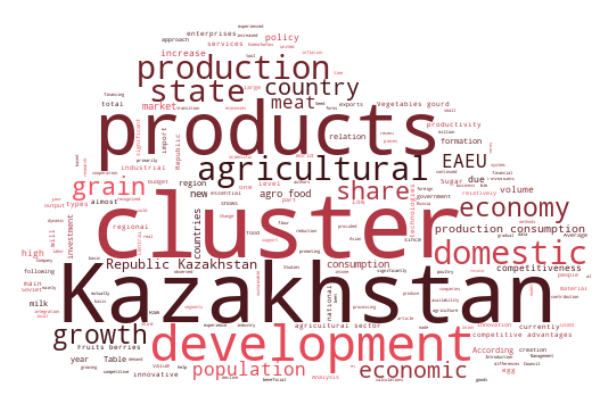

Word Cloud Generated by:

https://wordscloud.pythonanywhere.com/

\section{ABSTRACT}

Introduction. The relevance of the study is related to the fact that the formation of national clusters is one of the most essential tools to promote innovation and industrial development of the state economy. The objective of the article is to consider the peculiarities of the formation of cluster policy in the Republic of Kazakhstan and assess its development.

Materials and methods. Statistical data from the official website of the Committee on Statistics of the Republic of Kazakhstan, as well as scientific papers on the economic development of Kazakhstan and the EAEU countries, were used.

Results. The grain processing cluster of Kazakhstan is the basis of the agro-food cluster. In terms of grain production, Kazakhstan ranks third in the CIS after Russia and Ukraine. Wheat exports are one of the primary sources of foreign exchange earnings in the country's economy.

The market share of Kazakhstan for most products in relation to the EAEU is from 5 to $15 \%$. The highest shares are observed in the production/consumption of vegetables and gourd (22.48\%), grain $(14.34 \%)$, and milk (11.92\%). The lowest shares of production are observed for the production/consumption of sugar $(3.87 \%)$, fruits and berries $(7.47 \%)$, eggs $(8.76 \%)$, and meat (8.54\%). Agro-food production in Kazakhstan increased by 1.04\% from 2013 to 2018, while consumption increased by $0.60 \%$.

By 2035, the capacity of the EAEU domestic market could grow significantly in the segments: meat and meat products (by 15\%), milk and dairy products (by 17\%), fruits and berries (by 39\%), vegetables and gourd (by 24\%), grain (by 12\%) and oilseeds (by 69\%).

Discussion and conclusion. The formation and development of territorial and sectoral clusters, mainly agrarian, will be one of the most effective forms of realization of the national competitive advantages of the Republic of Kazakhstan.

Vasilyeva, O. A. (2021). Agro-food clusters in the Republic of Kazakhstan: assessment and prospects of development. Economic consultant, 34 (2), 13-20. doi: 10.46224/ecoc.2021.2.2 


\section{INTRODUCTION}

$T^{-1}$ oday, clusters are recognized as one of the most important tools for promoting innovative and industrial development, competitiveness, and the state economy's competitiveness.

A cluster is generally understood as a mutually beneficial cooperation of companies united to produce competitive, innovative products and services based on modern technologies and business models. The cluster approach is associated with creating new industries and services with a high level of added value and knowledge intensity, strengthening the state's competitive advantages in the world market.

Analysis of the world practice of cluster development shows that this approach has been widely developed in the strategies of many countries: the United States, the European Union, and Southeast Asia. According to experts, clustering currently covers about $50 \%$ of the economies of the leading countries of the world.

Practical experience in cluster formation shows that clusters are formed "from below" in innovative development and with the help of three components: science, business, and state support.

Following the Decree of the Government of the Republic of Kazakhstan of October 11, 2013, No. 1092 "On approval of the concept for the formation of promising national clusters of the Republic of Kazakhstan until 2020", clusters are recognized as an essential tool for promoting innovation, industrial development, competitiveness and efficiency of the state's economy [1].

The objective of the article is to consider the peculiarities of the formation of cluster policy in the Republic of Kazakhstan and assess the development of the agro-food cluster.

\section{MATERIALS AND METHODS}

The research materials were statistical data from the official website of the Committee on Statistics of the Republic of Kazakhstan.

Theoretical methods were used: analysis of works devoted to the economic development of Kazakhstan and articles of scientific periodicals: Studies on Russian Economic Development, Economic Change and Restructuring, Comparative Economic Studies, and Journal of Productivity Analysis.

\section{LITERATURE REVIEW}

The Republic of Kazakhstan is a Central Asian country that was formerly part of the Soviet Union. Kazakhstan has significant differences from other Central Asian 
countries. It is a large state with a relatively small population density: 6.93 people per square kilometer.

Kazakhstan's secession from the USSR, i.e., its independent status, was a complicated process since the republic was $93 \%$ tied to the Soviet economy.

Johan F. M. Swinnen and Liesbet Vranken analyze changes in agricultural production in Central and Eastern Europe and the former Soviet republics since the beginning of the transition. Scientists state that almost all countries with economies in transition have begun to experience an initial decline in productivity over the past twenty years, and almost all countries are currently experiencing an increase in productivity [14]. These facts can be explained by the following circumstances.

In the mid-1990s, Kazakhstan experienced an economic recession. The country's economy was under the high inflation, imbalanced revenues and expenditures of the budget system, a sustainable budget deficit, rising energy prices, and an uncontrolled monopoly of producers. In 1995, the economy of Kazakhstan experienced a slowdown in the economic downturn and a significant reduction in the level of inflation, which was achieved with the help of monetary policy instruments.

The government of Kazakhstan used oil revenues to diversify the economy, and billions of dollars were used to implement the agricultural and food development program for 2003-2005 [12].

Quite a heavy blow to the Kazakhstan financial system occurred in 2008. For the first time since the global crisis of 2009, investment growth has accelerated in the republic. This was primarily due to the ongoing integration of the country into the EAEU, which ensures the free movement of capital, goods, and labor in its territory [6].

Agricultural financing is an essential aspect of economic reform in Kazakhstan. However, according to Gaisina, the state financial support of agriculture was sporadic, and the investment climate in Kazakhstan was not favorable for lending to the agricultural sector.

Kazakhstan's economy in 2013 was characterized by a gradual decline in the country's GDP growth rates, although continued to remain significantly higher than regional ones. The steady growth in consumption of the population exceeded $11 \%$ per year and roughly corresponded to the average growth in recent years. The number of consumers in the republic continued to increase due to population growth. In addition, a large grain harvest provided an increase in agricultural output by $10.8 \%$.

Currently, Kazakhstan has national advantages in developing the agricultural sector, as it has the most suitable agricultural land, rich in highly qualified personnel. A significant contribution to the modernization of the agricultural sector, in the authors' opinion, can be made by structural transformations through the creation of production clusters and the introduction of cluster technologies in the real agricultural sector, both at the local and regional levels. 


\section{FEATURES OF CLUSTER POLICY IMPLEMENTATION IN KAZAKHSTAN}

Currently, cluster initiatives in Kazakhstan are an essential part of the country's industrial, regional, and innovation policy. They enhance the growth and competitiveness of clusters within regions that involve cluster companies, government, and academia.

Implementing a new cluster policy in Kazakhstan will create the basis for an innovative model of development and new competitive advantages of the domestic economy, increasing the competitiveness of basic and new sectors of the economy, small and medium-sized businesses, and sustainable development of the regions.

Clusters of the agro-industrial complex:

- Cluster Council chaired by the Minister of Agriculture of the Republic of Kazakhstan;

- integrator: NUH KazAgro Joint-Stock Company;

- Council members: the National Chamber of Entrepreneurs (industry association), industry research institutes, AEO Nazarbayev University, JSC SEZ PIT Management Company, universities.

The following key indicators of cluster performance are provided:

1. the amount of tax revenues to the state budget;

2. the share of the cluster's output in the total volume of the region's output;

3. cluster labor productivity;

4. the share of exports of cluster products and services in the total volume of non-resource exports;

5. the share of the cluster's goods and services sold in the total volume of the region's products sold;

6. EBITDA;

7. the net profit of enterprises;

8. the share of attracted investments for the development of cluster enterprises in the total investment volume of the region.

\section{RESULTS}

According to Table 1, the grain processing cluster of Kazakhstan is the basis of the agro-food cluster [11].

In terms of grain production, Kazakhstan ranks third in the CIS after Russia and Ukraine. Wheat exports are one of the primary sources of foreign exchange earnings in the country's economy.

For convenience, the data is presented in relative terms (see Table 2). 
Table 1

Domestic production and consumption of the main types of agro-food products in Kazakhstan in relation to the EAEU ( $\mathrm{mln}$. tons)

\begin{tabular}{|l|c|c|c|c|}
\hline Agricultural products & Production, 2013 & Consumption, 2013 & Production, 2018 & Consumption, 2018 \\
\hline Seed & $18.23 / 120.48$ & $12.81 / 89.49$ & $20.27 / 141.80$ & $13.76 / 100.89$ \\
\hline Potato & $3.34 / 35.37$ & $3.35 / 36.38$ & $3.81 / 33.93$ & $3.71 / 34.60$ \\
\hline Vegetables and gourd & $4.95 / 22.83$ & $5.94 / 26.66$ & $6.22 / 25.72$ & $6.08 / 27.91$ \\
\hline Fruits and berries & $0.28 / 4.78$ & $1.13 / 12.94$ & $0.39 / 6.12$ & $1.20 / 13.44$ \\
\hline Meat & $0.87 / 10.85$ & $1.14 / 13.21$ & $1.06 / 13.24$ & $1.30 / 13.70$ \\
\hline Raw milk & $4.93 / 43.49$ & $5.62 / 49.81$ & $5.69 / 45.93$ & $6.12 / 48.22$ \\
\hline Eggs (bln. pieces) & $3.90 / 50.17$ & $3.94 / 50.26$ & $5.59 / 55.12$ & $5.06 / 54.51$ \\
\hline Sugar (beet) & $0.01 / 5.19$ & $0.46 / 6.76$ & $0.08 / 7.11$ & $0.50 / 6.81$ \\
\hline
\end{tabular}

Table 2

Domestic production and consumption of the main types of agro-food products in Kazakhstan in relation to the EAEU (in \%)

\begin{tabular}{|l|c|c|c|c|c|}
\hline \multicolumn{1}{|c|}{ Agricultural products } & $\begin{array}{c}\text { Production, } \\
2013\end{array}$ & $\begin{array}{c}\text { Consumption, } \\
2013\end{array}$ & $\begin{array}{c}\text { Production, } \\
2018\end{array}$ & $\begin{array}{c}\text { Consumption, } \\
2018\end{array}$ & Average values \\
\hline Seed & $15.13 \%$ & $14.31 \%$ & $14.29 \%$ & $13.64 \%$ & $14.34 \%$ \\
\hline Potato & $9.44 \%$ & $9.21 \%$ & $11.23 \%$ & $10.72 \%$ & $10.15 \%$ \\
\hline Vegetables and gourd & $21.68 \%$ & $22.28 \%$ & $24.18 \%$ & $21.78 \%$ & $22.48 \%$ \\
\hline Fruits and berries & $5.86 \%$ & $8.73 \%$ & $6.37 \%$ & $8.93 \%$ & $7.47 \%$ \\
\hline Meat & $8.02 \%$ & $8.63 \%$ & $8.01 \%$ & $9.49 \%$ & $8.54 \%$ \\
\hline Raw milk & $11.34 \%$ & $11.28 \%$ & $12.39 \%$ & $12.69 \%$ & $11.92 \%$ \\
\hline Eggs (bln. pieces) & $7.77 \%$ & $7.84 \%$ & $10.14 \%$ & $9.28 \%$ & $8.76 \%$ \\
\hline Sugar (beet) & $0.19 \%$ & $6.80 \%$ & $1.13 \%$ & $7.34 \%$ & $3.87 \%$ \\
\hline Average values & $9.93 \%$ & $11.14 \%$ & $10.97 \%$ & $11.73 \%$ & $10.94 \%$ \\
\hline
\end{tabular}

Table 2 shows that the market share of Kazakhstan for most products in relation to the EAEU is from 5 to $15 \%$. The highest shares are observed in the production/consumption of vegetables and gourd $(22.48 \%)$, grain $(14.34 \%)$, and milk (11.92\%). The lowest shares of production are observed for the production/consumption of sugar $(3.87 \%)$, fruits and berries $(7.47 \%)$, eggs $(8.76 \%)$, and meat (8.54\%).

Agro-food production in Kazakhstan increased by $1.04 \%$ from 2013 to 2018, while consumption increased by $0.60 \%$.

According to the calculations of Ksenofontov et al., Kazakhstan demonstrated dynamic growth of domestic consumption of almost all types of agro-food products. This is due to the growth of the population's real incomes and the increase in the country's population from 16.0 million people in 2008 to 18.4 million people in 2018. The growing domestic demand for meat products and fruits was primarily met by the expansion of import volumes. In other segments, except for the sugar market, the share of imports in domestic consumption remained relatively low [8]. 
In Kazakhstan, there has been a trend towards a moderate reduction in imports in recent years on the background of the development of domestic milk production $(+1.05 \%)$. Kazakhstan is a major grain exporter. Up to 50-60\% of flour production is sent to foreign markets. The bulk of the surplus grain and flour is exported to third countries.

According to the calculations of Ksenofontov et al., by 2035, the capacity of the EAEU domestic market can significantly increase in the segments: meat and meat products (by $15 \%$ ), milk and dairy products (by 17\%), fruits and berries (by 39\%), vegetables and gourd (by 24\%), grain (by 12\%) and oilseeds (by 69\%). The main contribution to the overall increase in domestic consumption of agro-food products will be made by Russia (50-80\% for most products), due to its large share in the EAEU market, and Kazakhstan (15-30\%) - due to the high expected dynamics of population growth and per capita consumption of basic food products [8, p. 166].

\section{DISCUSSION}

There are differences in mutual trade between the EAEU countries on almost all the selected products. As noted by the authors: "Most of them are related to the problems of the development of agricultural production in the EAEU under the influence of severe limitations on the part of domestic demand, due to the low purchasing power of the population's income and the gradual approach to the physical limits of saturation of the food needs" [9].

The high availability of grain in Kazakhstan contributed to the development of grainintensive types of animal husbandry (mainly egg and broiler poultry). In the meat market, this may lead to a decrease in import volumes. At the same time, the consumption of poultry meat is still relatively low and has a high potential for growth in the coming years.

Paying attention to the cluster policy of Kazakhstan in general and agroclusterization in particular, the main signs of the creation of such clusters should be:

- integration and cooperation of agricultural firms, scientific institutions, and local and regional authorities based on new cluster technologies;

- innovations and new technologies in the organization and management of production, sales of products;

- financing of investments that can give new opportunities to agricultural formations in the competitive struggle.

Therefore, the formation and development of territorial and sectoral clusters, mainly agrarian, will be one of the most effective forms of realization of the national competitive advantages of the Republic of Kazakhstan. The creation of such agroclusters will become a strategic task of the state, and their effectiveness depends on the level of development of intersectoral relations, forms of interaction between enterprises, and mutually beneficial economic relations between partners. 


\section{CONCLUSION}

Despite the low competitiveness of manufactured products and the underdeveloped infrastructure in the Republic of Kazakhstan, there are several competitive advantages: the possibility of expanding the raw material base, the availability of production capacities of processing enterprises, natural and climatic conditions for growing agricultural products, the ability to produce finished products in a wide range and provide the country's population with high-quality products of domestic production.

\section{REFERENCES}

1. Resolution of the Government of the Republic of Kazakhstan No. 1092 "On Approval of the Concept for the Formation of Promising National Clusters of the Republic of Kazakhstan until 2020". (2013, October 11). Retrieved February 18, 2020, from http:// adilet.zan.kz/rus/docs/P1300001092

2. Alpysbaeva, S.N., Abylkasimova, M.E., \& Kalimova, D.M. (2015). Volumes of labor migration in the Republic of Kazakhstan. Studies on Russian Economic Development, 26, 510-516.

3. Aubakirova, G.M. (2013). Strategic priorities of the innovative development of a postindustrial economy (by the example of the Republic of Kazakhstan). Studies on Russian Economic Development, 24, 470-479. https://doi.org/10.1134/S1075700713050031

4. Baikova, E.I., \& Vardiashvili, N.N. (2015). On indicators of improved standards of living in Kazakhstan. Studies on Russian Economic Development, 26, 517-523. https://doi. org/10.1134/S1075700715050032

5. Howie, P., \& Atakhanova, Z. (2020). Heterogeneous labor and structural change in lowand middle-income, resource-dependent countries. Economic Change and Restructuring, 53, 297-332 (2020). https://doi.org/10.1007/s10644-018-9242-9

6. Khitakhunov, A., Mukhamediyev, B., \& Pomfret, R. (2017). Eurasian Economic Union: present and future perspectives. Economic Change and Restructuring, 50, 59-77. https:// doi.org/10.1007/s10644-016-9182-1

7. Klotsvog, F.N., Sukhotin, A.B. \& Chernova, L.S. (2009). Forecast of economic growth in Russia, Belarus, Kazakhstan, and Ukraine within the unified economic space. Studies on Russian Economic Development, 20, 366-372. https://doi.org/10.1134/ S1075700709040029

8. Ksenofontov, M.Yu., Polzikov, D.A., \& Urus, A.V. (2020). Scenarios for the development of the EAEU agro-food market in the long term. Forecasting Problems, 6(183), 154-171.

9. Ksenofontov, M.Y., Polzikov, D.A., \& Urus, A.V. (2020). Scenarios of the EAEU Agricultural Market Development in the Long Term. Studies on Russian Economic 
Development, 31, 700-716. https://doi.org/10.1134/S107570072006009X

10. Lukmanova, G., Baisholanova, K., Shiganbayeva, N., Abenov, B., Sambetbayeva, A., \& Gussenov, B.Sh. (2019). Innovative development of the agricultural sector of the Republic of Kazakhstan. Espacios, 40(32), 6.

11. Materials of the official website of the Committee on Statistics of the Republic of Kazakhstan. (n.d.). Retrieved February 18, 2020, from https://stat.gov.kz/

12. Pomfret, R. (2009). Using energy resources to diversify the economy: agricultural price distortions in Kazakhstan. Comparative Economic Studies, 51, 181-212. https://doi. org/10.1057/ces.2008.48

13. Soloviev, S.A., \& Goryachev, S.A. (2016). On the modernization of engineering systems in the farming industries of Russia, Belarus, and Kazakhstan. Studies on Russian Economic Development, 27, 114-117. https://doi.org/10.1134/S1075700716010147

14.Swinnen, J.F.M., \& Vranken, L. (2010). Reforms, and agricultural productivity in Central and Eastern Europe and the Former Soviet Republics: 1989-2005. Journal of Productivity Analysis, 33, 241-258. https://doi.org/10.1007/s11123-009-0162-6

15.Zubarevich, N.V., \& Safronov, S.G. (2011). Regional inequality in large postsoviet countries. Regional Research of Russia, 1, 15. https://doi.org/10.1134/ S2079970511010138

\section{INFORMATION ABOUT THE AUTHOR}

Olga A. Vasilyeva (Russian Federation, Chelyabinsk) - Lecturer at the Department of Economics. Kostanay branch. Chelyabinsk State University. E-mail: vasilolga@mail.ru

\section{(1) (1) \\ open Access}

Available: https://statecounsellor.wordpress.com/2021/05/30/vasilyeva-3/

Received: Feb 3, 2021 | Accepted: Apr 2, 2021 | Published: Jun 1, 2021

Editor: Daniela Antonescu, PhD in Economics. Romanian Academy, ROMANIA

Copyright: ( 2021 Vasilyeva, O. This is an open access article distributed under the terms of the Creative Commons Attribution License, which permits unrestricted use, distribution, and reproduction in any medium, provided the original author and source are credited.

Competing interests: The authors have declared that no competing interests exist. 